\title{
Pelatihan Dasar Kewaspadaan Bencana dan Evakuasi Mandiri di Pondok Modern Muhammadiyah Pakusari Kabupaten Jember
}

\author{
Bakhtiyar Hadi Prakoso $^{1 *}$, Gandu Eko Julianto Suyoso ${ }^{2}$, Mudafiq Riyan Pratama ${ }^{3}$, \\ Muhammad Yunus ${ }^{4}$, Angga Rahagiyanto ${ }^{5}$ \\ 1,2,3,4,5 Jurusan Kesehatan, Politeknik Negeri Jember \\ ${ }^{1}$ bakhtiyar.hp@polije.ac.id, ${ }^{2}$ gandu.eko.js@ polije.ac.id, ${ }^{3}$ mudafiq.riyan@polije.ac.id, ${ }^{4}$ m.yunus@polije.ac.id, \\ ${ }^{5}$ rahagiyanto@polije.ac.id
}

\begin{abstract}
Jember Regency is not immune from the risk of disasters. Information released by BPBD of Jember Regency, in 2018 there have been 224 disasters. This figure has increased more than 100\% from the number of events in 2017. Efforts to reduce the risk of existing disasters and prevent new risks can be done by increasing the resilience of the community. From this background the writer through community service activities held a basic training on disaster alert at the Muhammadiyah Modern Pakusari Pondok. In the training the material will be delivered with lectures and demonstrations. With this training the insights of the participants will increase, especially in the field of disaster alertness. In addition participants were also trained to evacuate themselves against the earthquake disaster
\end{abstract}

Keywords : Training, Disasters, Earthquakes

\begin{abstract}
Abstrak
Kabupaten Jember tidak luput dari risiko terjadinya bencana. Informasi yang dirilis oleh BPBD Kabupaten Jember, pada tahun 2018 telah terjadi kejadian bencana sejumlah 224 kejadian. Angka tersebut naik lebih dari 100\% dari jumlah kejadian tahun 2017. Upaya mengurangi risiko bencana yang sudah ada maupun mencegah terjadinya risiko baru dapat dilakukan dengan meningkatkan ketangguhan masyarakat. Dari latar belakang tersebut penulis melalui kegiatan pengabdian masyarakat mengadakan pelatihan dasar kewaspadaan bencana di Pondok Modern Muhammadiyah Pakusari. Dalam pelatihan tersebut materi akan disampaikan dengan ceramah dan demonstrasi. Dengan adanya pelatihan ini wawasan para perserta menjadi semakin bertambah terutama dalam bidang kewaspadaan bencana. Selain itu peserta juga dilatih untuk mengevakuasi diri sendiri terhadap bencana gempa bumi
\end{abstract}

Kata Kunci: Pelatihan, Bencana, Gempa Bumi

*Penulis Korespondensi : Bakhtiyar Hadi Prakoso

\section{PENDAHULUAN}

Bencana adalah peristiwa yang mengancam dan mengganggu kehidupan dan penghidupan masyarakat yang disebabkan baik oleh faktor alam atau faktor nonalam maupun faktor manusia sehingga mengakibatkan timbulnya korban jiwa manusia, kerusakan lingkungan, kerugian harta benda, dan dampak psikologis. Sedangkan Mitigasi bencana adalah 
serangkaian upaya untuk mengurangi risiko bencana, baik melalui pembangunan fisik maupun penyadaran dan peningkatan kemampuan menghadapi ancaman bencana.[1]

Indonesia terletak di kawasan Cincin Api Pasifik yang secara geografis dan klimatologi mempunyai tantangan untuk melindungi dan memperkuat masyarakat dari ancaman risiko bencana. Pergerakan tiga lempeng tektonik besar, yaitu lempeng Indo Australia di bagian selatan, lempeng Samudera Pasifik di sebelah timur, lempeng Eurasia di sebelah utara (dimana disebagian besar wilayah Indonesia) dan disertai daerah aliran sungai (5.590 DAS) mengakibatkan risiko bencana geologi. Dampak pemanasan global dan pengaruh perubahan iklim pada wilayah perairan laut Indonesia cenderung menimbulkan potensi terjadinya berbagai jenis bencana hidrometeorologi. [2]

Topografi Kabupaten Jember yang lengkap, yaitu dari daerah dataran tinggi hingga pesisir membuat Kabupaten Jember tidak luput dari risiko terjadinya bencana. Informasi yang dirilis oleh BPBD Kabupaten Jember, pada tahun 2018 telah terjadi kejadian bencana sejumlah 224 kejadian. Angka tersebut naik lebih dari 100\% dari jumlah kejadian tahun 2017. Bila dirunut ke belakang ternyata grafik tren jumlah kejadian bencana di Kabupaten Jember dalam 5 tahun terakhir mengalami peningkatan. Hampir seluruh jenis kejadian bencana pernah terjadi di Kabupaten Jember, sebut saja erupsi gunung berapi, banjir, angin kencang, tanah longsor, pergerakan tanah, gelombang tinggi, kebakaran hutan, kekeringan, dan gempa bumi. Di antara bermacam bencana tersebut, angin kencang menjadi jenis bencana yang mendominasi pada tahun 2018.[3]

Peta risiko bencana gempa bumi yang dirilis oleh BNPB pada tahun 2017 menjelaskan bahwa Kabupaten Jember memiliki risiko bencana dari tingkat ringan hingga tinggi, tergantung jenis bencana dan lokasinya. Contohnya banjir dan angin kencang memiliki risiko sedang hingga tinggi. Gempa bumi secara umum di Kabupaten Jember memiliki risiko rendah hingga sedang, namun tsunami memiliki risiko rendah hingga tinggi. Tingginya potensi ancaman dan jumlah masyarakat yang terpapar risiko bencana menyebabkan perlunya meningkatkan kemampuan dan keterampilan masyarakat secara terus menerus sehingga masyarakat di seluruh Indonesia dapat mengetahui bagaimana harus merespon dalam menghadapi situasi kedaruratan bencana.[4]

Kesiapsiagaan dan ketrampilan masyarakat, khususnya keluarga menjadi kunci utama keselamatan dalam menghadapi bencana. Satu contoh kasus yang terjadi di Kabupaten Jember tahun 2018, seorang warga meninggal dunia karena terpeleset saat berusaha lari menyelamatkan diri keluar rumah ketika terjadi gempa bumi. Hal ini menunjukkan bahwa pengetahuan yang kurang bisa berakibat fatal pada masyarakat. Berdasarkan survei pada kejadian gempabumi Hanshin-Awaji Jepang tahun 1995 menunjukkkan bahwa 34,9 \% korban dapat selamat karena upaya penyelamatan diri mandiri; $31,9 \%$ selamat dengan bantuan anggota keluarga; 28,1\% selamat karena pertolongan teman/tetangga; 2,6\% selamat ditolong oleh orang yang pada saat kejadian dekat dengan korban; 1,7 \% dibantu oleh tim penyelamat. Survei tersebut menunjukkan bahwa sebagian besar korban selamat adalah karena dirinya sendiri dan orang-orang di sekitarnya terutama keluarga, bukan dari tim penolong.

Upaya mengurangi risiko bencana yang sudah ada maupun mencegah terjadinya risiko baru dapat dilakukan dengan meningkatkan ketangguhan masyarakat. Masyarakat sebagai korban terdampak bencana memiliki risiko yang dapat berupa kematian, luka, sakit, jiwa terancam, hilangnya rasa aman, mengungsi, kerusakan atau kehilangan harta, dan gangguan kegiatan masyarakat risiko tersebut dapat dikurangi ataupun dicegah apabila ketangguhan telah terbentuk dalam diri masyarakat.[5] Salah satu risiko yang paling tinggi didalam masyarakat yang perlu dikelola adalah kelompok rentan. Kelompok rentan terdiri dari bayi, balita, dan anak-anak, ibu yang sedang mengandung atau menyusui, penyandang cacat dan orang lanjut usia. Dalam lapisan masyarakat anak-anak merupakan anggota masyarakat yang paling terakhir didengar dan dimintai pendapatnya serta jarang diberi kesempatan untuk didengar terkait kekhawatiran dan pengalaman mereka terkait bencana.

\section{METODE}

Kegiatan pengabdian kepada masyarakat dibagi menjadi tiga tahapan utama seperti yang dijelaskan pada gambar 1 berikut ini

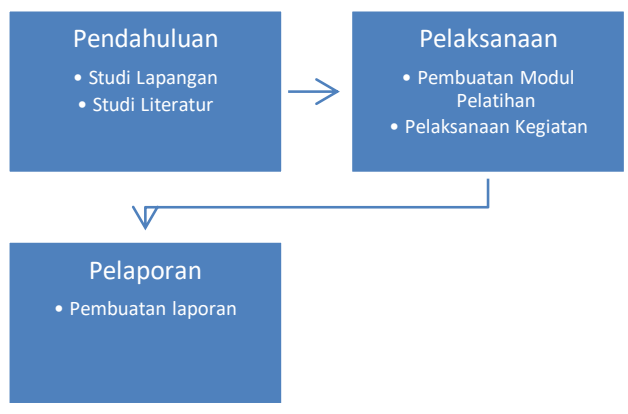

Gambar 1. Tahapan Pelaksanaan Kegiatan Kepada Masyarakat 


\section{1) Tahapan Pendahuluan}

Tahapan pendahuluan merupakan kegiatan pendahuluan dimana kegiatan ini meliputi kegiatan studi lapangan ke tempat pengabduian kepada masyarakat dilakukan. Kegiatan ini berupa penggalian informasi terkait dengan kondisi Pondok Modern Muhammadiyah Pakusari. Proses penggalian informasi dilakukan dengan melakukan wawancara terhadap Pemilik Pondok. Pada tahapan ini juga dilakukan studi literatur. Adapun studi literatur yang dilakukan adalah dengan mempelajari teori teori yang terkait dengan kewaspadaan bencana. Proses studi leteratur mengambil refererensi dari internet dan buku-buku yang berkaitan dengan tema yang menjadi pokok bahasan.

\section{2) Tahapan Pelaksanaan}

Pada tahapan pelaksanaan proses yang dilakukan pertama kali adalah dengan membuat modul pelatihan. Adapun materi pembuatan modul pelatihan meliputi

- Kondisi kebencanaan Indonesia

Pembahasan ini difokuskan pada koondisi kebecanaan di indoensi dimana Indonesia terletak di antara tiga lempeng yaitu ( Indo-Australia,Eurasia dan Pasifik) memberikan dampak yang menguntungkan dari segi sumber daya alam seperti minyak bumi, batu bara, lautan yang luas, hutan, dan sebagainya

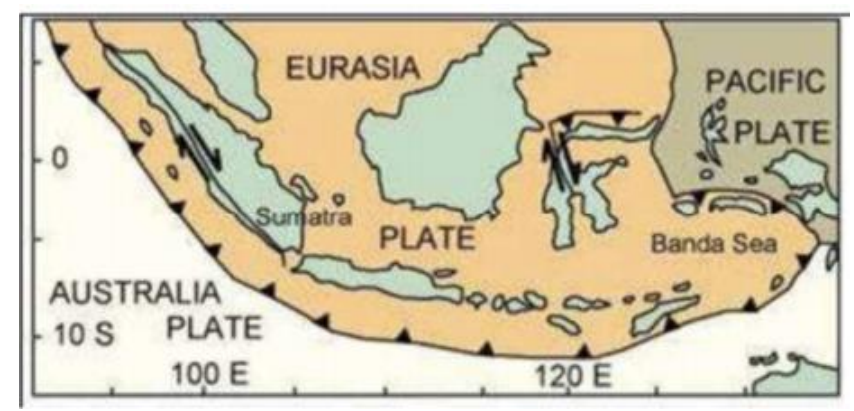

Gambar 2. Kondisi Geologis Indonesia

Selain itu juga dijelaskan tentang berbagai macam jenis bencana yang terjadi di Indonesia, dimana data-data ini dihimpun oleh BNPB 2019 tercatat telah

terjadi 3.814 kali bencana. Jenis bencana alam yang paling tinggi angka kejadiannya adalah angin puting beliung, sedangkan jenis bencana alam yang angkanya meningkat dari drastis dibandingkan tahun 2018 adalah kebakaran hutan dan lahan. Adapun dampak bencana yang ditimbulkan antara lain 478 orang meninggal dunia, 111 orang hilang, 3.422 orang luka luka, 6,1 juta orang menderita dan mengungsi, 73.726 rumah rusak, serta 2.024 fasilitas umum rusak.. 3 provinsi yang memiliki angka kejadian bencana lebih tinggi dari mayoritas provinsi di Indonesia adalah Jawa Barat, Jawa Tengah dan Jawa Timur [3].

- Pengertian dan macam-macam bencana

Pada bagian ini dijelaskan bebearapa materi berupa pengertian dan macam-macam bencana yang meliputi
a) Gempa bumi
b) Tsunami
c) Gunung Api
d) Banjir
e) Kekeringan
f) Angin topan
g) Tanah longsor
h) Kebakaran hutan dan lahan
i) Gelombang tinggi dan abrasi

- Kondisi kebencanaan di kabupaten Jember

Pada bagian ini menjeaskan kondisi bencana di kabupaten Jember

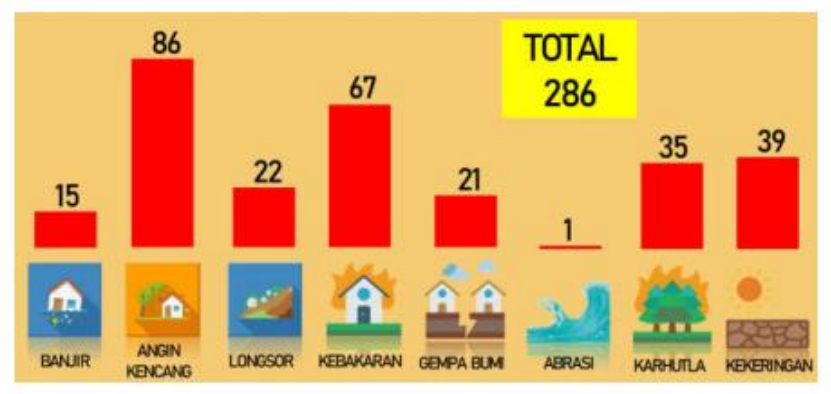

Gambar 3 Kejadian Bencana di Kabupaten Jember Sumber: BPPD kabupaten Jember

Dimana angka kejadian bencana tertinggi yaitu angin kencang

Selain pembuatan modul pelatihan, pada tahapan dilakukan perancangan kegiatan yang dilakukan pada saat pelaksanaan. Adapun tekniks kegiatan pengabdian kepada masyarakat "Pelatihan Dasar Kewaspadaan Bencana dan Evakuasi Mandiri di Pondok Modern Muhammadiyah Pakusari di Kabupaten Jember" dilaksanakan di tingkat SMP dan SMA dengan menggunakan tatap muka. Kegiatan tatap muka berupa ceramah, diskusi dan praktik.

a) Ceramah

Metode ceramaha merupakan sebuah metode yang berfokus pada sebuah interaksi penerangan maupun penuturan lisan dari seorang pemateri kepada para peserta. Dalam pelatihan ini peserta akan dibekali materi tentang kewaspadaaan bencana dengan menggunakan bantuan LCD dan laptop dalam penyampaian materinnya

b) Tanya Jawab 
Setelah pemaparan materi dengan menggunakan metode ceramah, peserta pelatiahan akan mendapatakan kesempatan tanya-jawab terhadap pemateri. Metode tanya jawab ini merupakan metode yang tergolong cukup efektif untuk meningkatkan pemahaman peserta pelatiahan. Dalam menggunakan metode tanya-jawab, ada beberapa hal yang harus diperhatikan. Pertama, jenis pertanyaan; kedua, teknik mengajukan pertanyaan; ketiga, memperhatikan syarat-syarat penggunaan metode tanya-jawab sehingga dapat dirumuskan langkah-langkah yang benar; keempat, memperhatikan prinsipprinsip penggunaan metode tanya jawab, di antaranya prinsip keserasian, integrasi, kebebasan, dan individual.

\section{c) Demonstarasi}

Setelah dilakukan sesi ceramah dan tanya jawab peserta didik akan diberikan materi praktik secara demonstrasi. Metode demonstrasi merupaan metode yang menggunakan alat peraga dalam memperjalas suatu materi atau untuk memperlihatkan bagaimana melakukan sesuatu dihadapan kepada para peserta. Metode ini dapat lebih mengutamakan gerakan atau demonstarasi secara langsung, sehingga peserta pelatihan diharapkan lebih cepat memahami materi yang disampaikan. Materi yang diberikan dengan metode demonstrasi ini adalah adalah praktik kewaspadaan terhadap bencana gempa bumi. Peserta pelatihan akan diperlihatkan simulasi secara langsung bagaimana gempa terjadi dan apa yang harus dilakukan ketika bencana gempa bumi itu terjadi.

3) Tahapan Pendahuluan

Tahapan ini merupakan tahapan terakhir dari pelakasanaan kegiatan pengabdian kepada masyarakat. Pada tahapan ini dilakukan penyusnan laporan dan pembuatan artikel dari kegiatan pengabdian kepada mayarakat yang telah dilakukan.

\section{HASIL DAN PEMBAHASAN}

Kegiatan Pengadian Kepada Masyarakat "Pelatihan Dasar Kewaspadaan Bencana dan Evakuasi Mandiri di Pondok Modern Muhammadiyah Pakusari di Kabupaten Jember" telah dilakasanankan dengan dua tahap. Sebagaian besar kegiatan berupa pemberian materi dan simulasi perlindungan diri, terkait dengan bencana. Materi diberikkan oleh Gandu Eko Julianto S.Ked., M.KKK , dimana beliau merupakan pakar dalam bidang K3 dan pernah aktif dalam BPBD (Badan Penanggulananga Bencana Daerah). Pembagian ini didasarkan pada peserta yang mengikuti kegiatan. Adapun rincian kegiatan pengabdian yang telah dilaksanakan di Pondok Modern Muhammadiyah Pakusari adalah sebagai berikut:

1) Tahap Pertama
Kegiatan pengabdian pada tahap pertama dilaksanakan pada bulan Februari. Kegiatan ini dikuti oleh peserta putra sebanyak 29 Orang. Kegiatan berlangsung dalam dua tahap yaitu sebagai berikut :

a) Minggu ke 3 bulan Februari

Kegiatan pada tahuapan ini meliputi pemberian materimateri dasar terkait dengan kewaspadaaan bencana dan evakuasi mendiri. Adapun materi yang disampaikan berupa

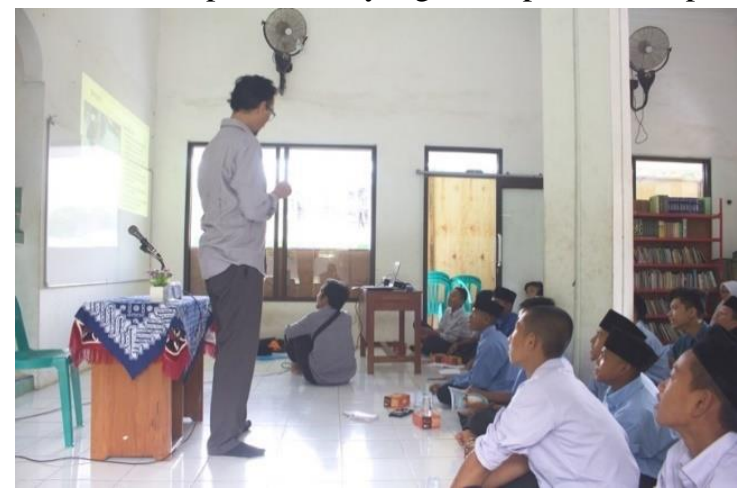

Gambar 4 Pemberian Materi Kewaspadaan Bencana

- Pengetahuan tentang kebencanaan terutama bencana gempa bumi

Pada bagian ini santri di Pondok Modern Muhammadiyah Pakusari Jember diberikan materi dasar terkait dengan kewasapadan, terutama gempa bumi. Para peserta pelatihan rata-rata belum memahami terkait dengan dengan bencana alam secara umum.

- Pengetahuan tentan kewaspadaan bencana gempa bumi

Pada bagian ini diberikan materi yang lebih spesifiki yaitu terkait dengan gempa bumi.

- Pengentahuan tentang penyelamatan diri terhadap bencana

Santri di pondok modern Muhammadiyah pakusari jember diberkan pengetahui praktik terkait penyelematan diri terhadap bencana bumi. Diharapkan dengan adanya praktik langsung ini dapat memberikan pengetahuan baru

b) Minggu ke 4 bulan Februari

Kegiatan pada tahuapan ini meliputi pemberian materi berupa praktik terkait dengan bagaimana upaya perlindungan diri terhadap bencana. Dalam kegiatan ini santri diberikan simulasi perlindungan diri jika terjadi bencana gempa bumi 


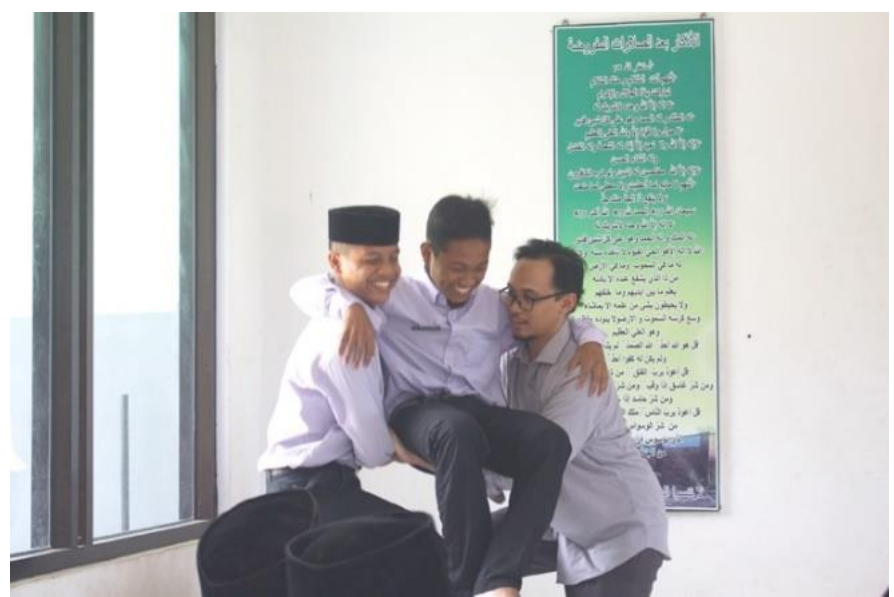

Gambar 5 Praktik Kewaspadaan Bencana

2) Tahap Kedua

Sama halnya dengan pelaksanaan kegiatan tahap kesatu. Kegiatan tahap kedua dilaksanakan pada bulan Maret. Kegiatan ini diikuti santriwati sebanyak 14 Orang. Kegiatan berlangsung dalam dua tahap yaitu sebagai berikut:

\section{a) Minggu ke 1 bulan Maret}

Kegiatan pada tahuapan ini meliputi pemberian materimateri dasar terkait dengan kewaspadaaan bencana dan evakuasi mendiri. Adapun materi yang disampaikan berupa

- Pengetahuan tentang kebencanaan terutama bencana gempa bumi

Pada bagian ini santri di Pondok Modern Muhammadiyah Pakusari Jember diberikan materi dasar terkait dengan kewasapadan, terutama gempa bumi. Para peserta pelatihan rata-rata belum memahami terkait dengan dengan bencana alam secara umum.

- Pengetahuan tentan kewaspadaan bencana gempa bumi

Pada bagian ini diberikan materi yang lebih spesifiki yaitu terkait dengan gempa bumi.

- Pengentahuan tentang penyelamatan diri terhadap bencana

Santri di pondok modern Muhammadiyah pakusari jember diberkan pengetahui praktik terkait penyelematan diri terhadap bencana bumi. Diharapkan dengan adanya praktik langsung ini dapat memberikan pengetahuan baru

b) Minggu ke 2 bulan Maret

Kegiatan pada tahaapan ini meliputi pemberian materi berupa praktik terkait dengan bagaimana upaya perlindungan diri terhadap bencana. Dalam kegiatan ini santri diberikan simulasi perlindungan diri jika terjadi bencana gempa bumi

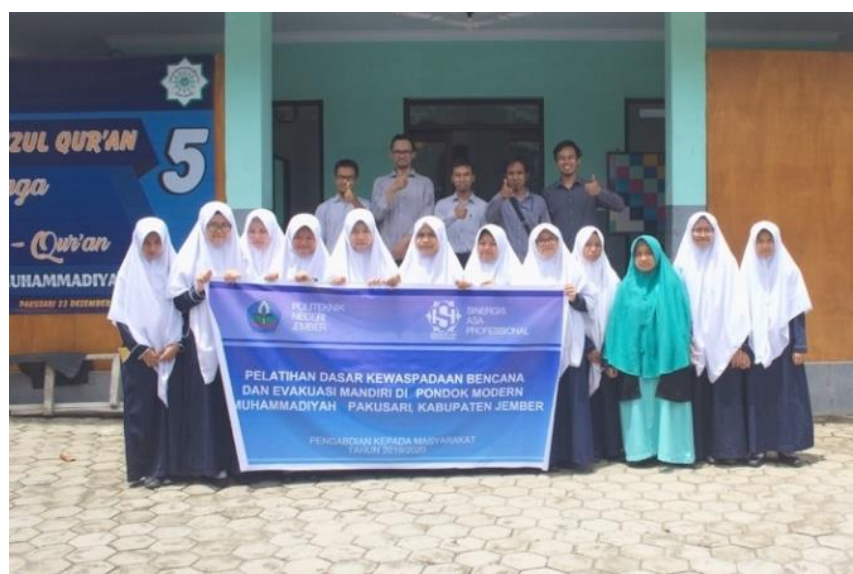

Gambar 6. Peserta Putri Pelatihan Kewaspadaan Bencana di Pondok Modern Muhammadiyah Pakusari

Kegiatan program pengabdian kepada masyarakat yang telah dilakukan di Pondok Pesantren Muhammadiyah Pakusari berjalan dengan lancer. Peserta cukup antusias dalam menerima materi. Dari proses interaksi yang telah dilakukan selama pemberian materi rata-rata peserta belum pernah mendapatkan pelatihan atau materi tentang kewaspadaan bencana. Rata-rata para peserta mendapatkan informasi tentang kewaspadaan bencana dari media luar. Pihak pondok pesantren belum menerapkan pelatihan secara rutin terkait dengan kewaspadaan bencana. Adanya pelatihan ini mendapatkan antusiasme yang tinggi dari pengelola Pondok Pesantren Modern Muhammadiyah Pakusari karena selama ini belum ada pelatihan serupa yang pernah diadakan.

\section{KESIMPULAN}

Kegiatan pengabdian kepada masyarakat ini dapat memberikan dampak yang positf bagi peserta pelatihan. Sebagian besar peserta pelatihan yaitu santri Pondok Pesantren Pakusari Jember masih belum memahami bahaya resiko dari bencana alam, terutama gempa bumi. Dengan adanya pelatihan ini wawasan para perserta menjadi semakin bertambah terutama dalam bidang kewaspadaan bencana. Selain itu peserta juga dilatih untuk mengevakuasi diri sendiri terhadap bencana gempa bumi. Hal ini dapat dijadikan sebuah tindakan prefentif dalam menanggulangi resiko akibat yang ditimbulkan oleh bencana mengingat Kabupaten Jember merupakan daerah yang dapat dikategorikan sebagai daerah rawan bencana. Keterbatasan waktu menjadi kendala dalam menyampaikan materi tentang kewaspadaan bencana ini. Sehingga materi yang disampaikan tidak seluruhnya dapat di sampaikan. Materi tentang kewaspadaan bencana sangat luas sehingga pihak Pondok Pesantren Modern Muhammadiyah Pakusari perlu 
menjadwalkan secara rutin agenda pelatihan kewaspadaan bencana ini, mengingat Kabupaten Jember ini merupakan daerah yang tergolong rawan bencana. Dengan pembekalan teori dan praktik tentang kewaspadaan bencana ini diharapkan siswa-siswi yang terdapat di Pondok Modern Muhammadiyah Pakusari dapat mendapatkan pengetahuan tentang bencana sehingga bisa meminimalisir resiko jika terjadi bencana.

\section{UCAPAN TERIMAKASIH}

Ucapan terimakasih disampaikan kepada Politeknik Negeri Jember yang telah memberikan kesempatan bagi penulis untuk melaksanakan kegiatan Pengabdian Kepada Masyarakat. Penulis juga tidak lupa mengucapkan terimakasih kepada pihk Pondok Modern Muhammadiyah Pakusari yang bersedia untuk mendajadi tempat bagi penulis untuk melaksanakan pengabduan.

\section{DAFTAR PUSTAKA}

[1] BNPB, Dokumen Kawasan Risiko Bencana Kabupaten Jember Tahun 2017-2021. Jakarta, 2017.

[2] H. Darman, An Outline of the Geology of Indonesia. Indonesian Assotiation of Geologist, 2000.

[3] BNPB, Buku Panduan Hari Kesiapsiagaan Bencana. Jakarta, 2018.

[4] A. Gunawan and P. Khadiyanto, "Kajian Aspek Bentuk Lahan dan Geologi Berdasarkan Mikrotremor dalam Perencanaan Ruang Kawasan Rawan Gempa di Kabupaten Bantul Daerah Istimewa Yogyakarta (Studi Kasus: Kecamatan Bantul, Jetis, Imogiri, dan Kretek), J. Pembang. Wil. Kota, vol. 8, no. 2, p. 178, 2012, doi: 10.14710/pwk.v8i2.11570.

[5] R. Indonesia, Penanggulangan Bencana. Jakarta, 2007. 